\title{
Histopathology and Antibiotic Susceptibility of Aeromonas hydrophila Isolated from Diseased Guppy (Poecilia reticulata)
}

\author{
Cigdem Urku \\ Istanbul University, Faculty of Aquatic Sciences, Department of Aquaculture and Fish Diseases, Istanbul, \\ Turkey
}

Received: 26/03/2019, Accepted: 17/03/2020

\begin{abstract}
This study was carried out to determine the reason of mortality in guppy (Poecilia reticulata) kept in an aquarium fish-rearing farm in Istanbul province and confirm damage caused in tissues and antibiotic susceptibility of isolated pathogen bacteria. Externally diseased guppies $(n=15)$ showed sloughing scales, ulcerative skin lesions on the body surface and abdominal distension; internally pale liver and accumulation of a liquid in the abdominal cavity were observed. Bacteriological inoculation from internal organs such as liver, spleen and kidney of guppies $(\mathrm{n}=15)$ were made onto Tryptic Soy Agar (TSA) and Brain Heart Infusion Agar (BHIA). After incubation, all isolated bacteria were identified as Aeromonas hydrophila according to their psychological, morphological, biochemical characteristic, and API 20E profile. Also, these isolates $(n=15)$ were determined to be sensitive to chloramphenicol and florfenicol. Histopathologically, multifocal liquefactive necrosis in the spleen, liver, kidney and heart, degeneration of tubular epithelium and necrosis in the kidney, desquamation of mucosa epithelium and necrotic gastric glands in the stomach, discharge of the white pulp in the spleen, desquamation of the lamina propria and mucosa epithelium in the intestine, and sloughed off the necrotic gill epithelium cells were observed.
\end{abstract}

Keywords: Aeromonas hydrophila, antibiotic susceptibility, API 20E, guppy, histopathology

\section{Hasta Lepistes Balığından (Poecilia reticulata) İzole Edilen Aeromonas hydrophila’ nın Antibiyotik Duyarlılığı ve Histopatolojisi}

\section{Öz}

Bu çalışma İstanbul ilinde bulunan bir akvaryum balığı üretim işletmesindeki hasta lepistes balıklarında görülen ölümlerin nedenini ortaya koymak ve izole edilen patojen bakterinin dokularda oluşturduğu hasarı ve antibiyotik duyarlılığını tespit etmek amacı ile yürütülmüştür. Eksternal olarak, ölmek üzere olan lepistes (Poecilia reticulata) balıklarında pullarda dökülme, vücut yüzeyinde ülseratif deri lezyonları ve abdominal genişleme görüldü; internal olarak karaciğerin renginde açılma, abdominal boşlukta sıvı birikimi tespit edildi. Karaciğer, böbrek ve dalak gibi iç organlardan Tryptic Soy Agar (TSA) and Brain Heart Infusion Agar (BHIA) besiyerlerine ekimler yapıldı. İnkubasyon sonrasında izole edilen tüm bakteriler fizyolojik, morfolojik ve biyokimyasal özellikleri ve API 20E profiline göre Aeromonas hydrophila olarak identifiye edildi. Bu izolatların ( $\mathrm{n}=15)$ kloramfenikol ve florfenikol'e duyarlı olduğu tespit edildi. Histopatolojik olarak dalak, karaciğer, böbrek ve kalp dokusunda multifokal liquefaktif nekroz, tubuler böbrek epitelyumunda dejenerasyon ve nekroz, mide bezlerinde ve mukoza epitelyumunda dökülme, dalağın kırmızı pulpasında boşalma, bağırsağın mukoza epitelinde ve lamina propriasında dökülme yanı sıra nekrotik solungaç epitel hücrelerinde dökülme tespit edilmiştir.

Anahtar Kelimeler: Aeromonas hydrophila, antibiyotik duyarlılı̆̆ı, API 20E, lepistes, histopatoloji

\footnotetext{
*Corresponding Author: curku@istanbul.edu.tr
} 


\section{Introduction}

Ornamental fish production is a profitable industry in the world. This industry has 60year history in Turkey; it is particularly involved in the production of fish such as guppy (Poecillia reticulata), angelfish (Pterophylum scalarae) and gold fish (Carassius auratus) (Savaş, 1996; Türkmen and Alpbaz, 1999). However, it has been reported that bacterial infections in the aquarium fish industry cause severe economic losses at every step of the production (Wildgoose, 2001).

Gram-negative, facultative anaerobic Aeromonas hydrophila is normal bacterial flora of fish and responsible for the disease known as Motile Aeromonas Disease (MAD) or Motile Aeromonas Septicemia (MAS) in fish at the time of the stress (Lewbart, 2001, Janda and Abbott, 2010; Austin and Austin, 2016). This bacterium also is a zoonotic pathogen causing infection in human ( $\mathrm{Li}$ and Saghaian, 2011) so an important pathogen both fish and human. A. hydrophila has been recovered as a pathogen from different ornamental fish species (Hettiarachchi and Cheong, 1994). Clinically, MAS is generally characterized by the presence of the body surface lesions and hemorrhages, eroded fins, sloughing scales, exophthalmia and abdominal distension (Hettiarachchi and Cheong, 1994; Pathiratne et al. 1994; Musa et al., 2008; Jagoda et al., 2014). A. hydrophila, the agent of MAS causes histologic damage in the liver and kidney of infected fish (ElBarbary, 2010).

The aim of the study is to determine the reason of mortalities in the diseased guppy (Poecilia reticulata) kept in an aquarium fish-rearing farm in Istanbul province, characterize the pathogen and determine the sensitivity of the agent involved to commonly used antibiotics with a view to provide the aquarists with the information on effective treatment and suitable treatment against agent caused mortality.

\section{Material and Method}

\subsection{Fish Samples}

Fifteen diseased guppy were obtained from an aquarium fish-rearing farm in Istanbul/Turkey.

\subsection{Bacteriology}

For microbiological analysis, samples were taken from liver, spleen and kidney from all diseased guppies. They were inoculated onto Brain Heart Infusion Agar (BHIA) and Tryptic Soy Agar (TSA). Petri plates were incubated during $24-48 \mathrm{~h}$ at $24-25 \mathrm{C}^{\circ}$. The isolates $(n=15)$ recovered from guppies were identified by using the conventional bacteriological method. In addition, fifteen isolates were determined together with their biochemical characteristics using API20E (Buller, 2004; Austin and Austin, 2016).

\subsection{Histopathology}

Samples of tissues from visceral organs (liver, kidney, spleen, gut, heart) and gill immediately fixed in $10 \%$ buffered formalin and processed for paraffin embedding. Histological sections $(4-5 \mu \mathrm{m})$ were stained with haematoxylin and eosin (H\&E) and examined by light microscopy (Bullock, 1978).

\subsection{Antibiotic Susceptibility}

Antibacterial susceptibility of our isolates were determined by using KirbyBauer disc diffusion method (Barry and Thornsberry, 1985). For this reason, 12 commercial 
antibiotic disc such as chloramphenicol (30 $\mu \mathrm{g} / \mathrm{disc})$, kanamycin $(30 \mu \mathrm{g} / \mathrm{disc})$, flumequine (30 $\mu \mathrm{g} /$ disc), erythromycin $(5 \mu \mathrm{g} /$ disc), streptomycin $(10 \mu \mathrm{g} / \mathrm{disc})$, ciprofloxacin (1 $\mu \mathrm{g} /$ disc $)$, sulphamethoxazole $(25 \mu \mathrm{g} /$ disc $)$, ampicillin (10 $\mu \mathrm{g} /$ disc), enrofloxacin (5 $\mu \mathrm{g} / \mathrm{disc}) \quad$ florfenicol $\quad(30 \mu \mathrm{g} / \mathrm{disc})$, oxytetracycline $(30 \mu \mathrm{g} /$ disc $)$ and furazolidone (50 $\mu \mathrm{g} /$ disc) (Oxoid, England) were used. The antibiotics sensitivity testing was carried out according to instruction of the Clinical and Laboratory Standart Institute (CLSI, 2008).

\section{Research Findings}

Fifteen diseased guppy exhibited externally large hemorrhagic ulcerative skin lesions on the body surface, sloughing scales, eroding fin and abdominal distension (Figure 1a); internally, pale liver, hemorrhage on the visceral organs and accumulation of a liquid in the abdominal cavity (Figure 1b). After incubation of kidney, spleen and liver swabs, cream colonies were observed on TSA and BHIA. Isolated bacteria $(n=15)$ were motile, Gram-negative basil, oxidase and catalase positive and resistant to O129/10-150. According to all biochemical tests result, isolates were identified as Aeromonas hydrophila (Table 1). In addition, of these biochemical results, all isolates showed 324612757 (96.9\%) API 20E profile number and thus biochemical result was confirmed with API-web results.

Histopathologically, multifocal liquefactive necrosis in the spleen, liver (Figure 2a), kidney and heart were observed. Tubular epithelium degeneration and necrosis was present in the kidney tissue (Figure 2b). Discharge of the white pulp in the spleen (Figure 2c), lymphocyte infiltration between the cardiac muscle (Figure 2d), desquamation of mucosa epithelium and necrotic gastric glands in the stomach, desquamation of the lamina propria and mucosa epithelium (Figure $2 \mathrm{e})$ and sloughed off the necrotic gill epithelium (Figure 2f) were observed.

All isolates were sensitive to florfenicol, chloromphenicol, enrofloxacin, flumequine, ciproflaxacin, sulphamethoxazole and highly resistant to erythromycine, oxytetracycline and ampicillin (Figure 3, Table 2).

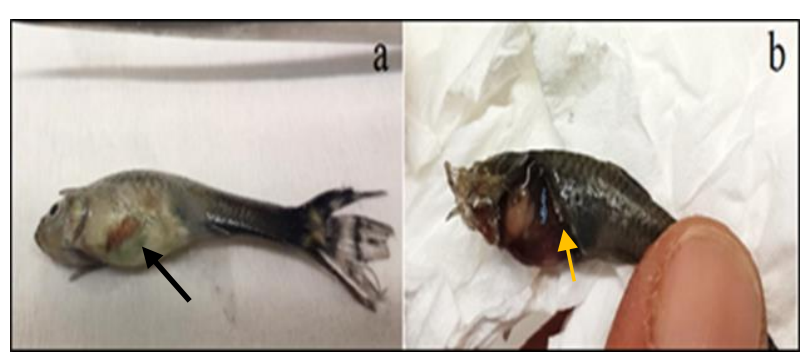

Figure 1. Diseased guppy infected with $A$. hydrophila;(a) ulcerative skin lesion (arrowed), eroding caudal fin (b) pale liver (arrowed) and accumulation of a liquid in the abdominal cavity

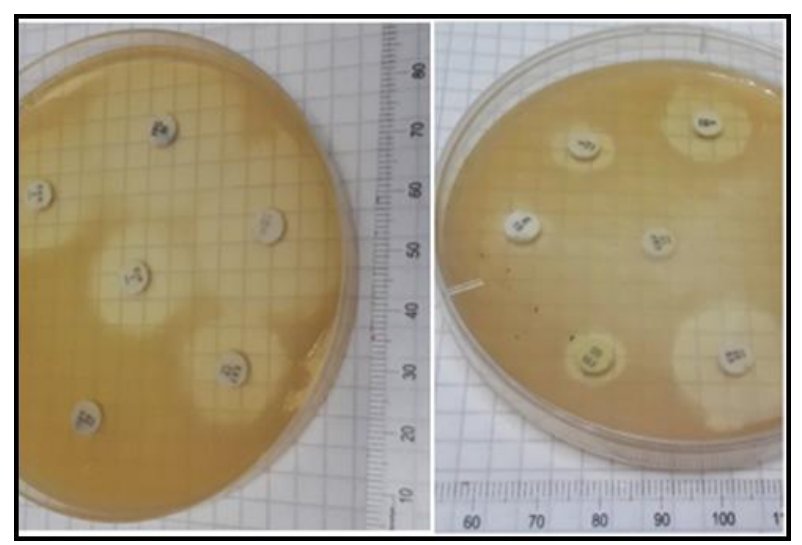

Figure 3. Antibiotic sensitivity test results of $A$. hydrophila 


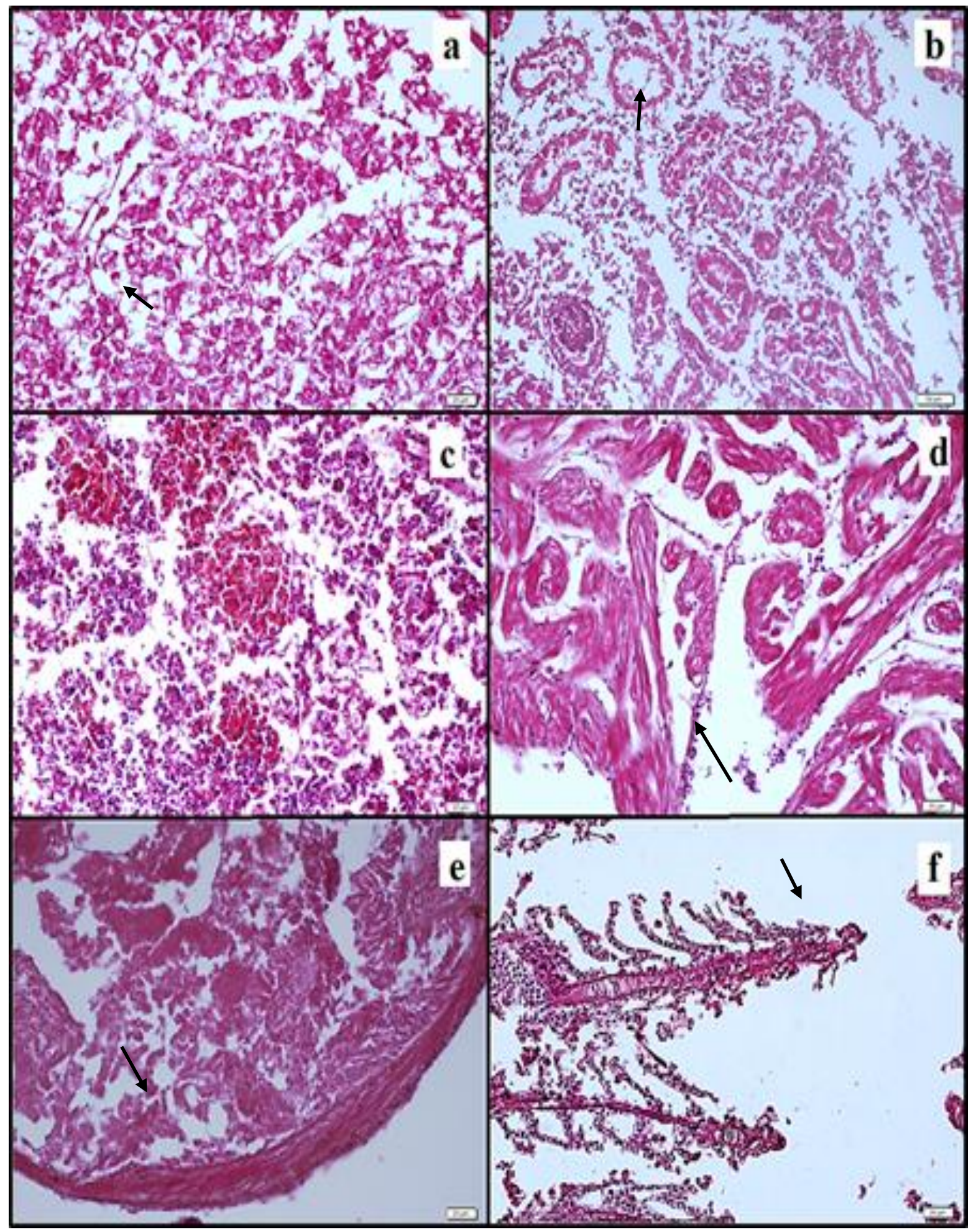

Figure 2. (a) Vacuolation (arrowed) and multifocal liquefactive necrosis; (b) degeneration and necrosis of the tubular epithelium (arrowed); (c) discharge of the white pulp; (d) lymphocyte infiltration between the cardiac muscle (arrowed); (e) desquamation of the lamina propria and mucosa epithelium (arrowed); (f) sloughed of the necrotic gill epithelium (arrowed) 
Tablo 1. Morphological, physiological and biochemical characteristics of the isolates recovered from diseased guppy

\begin{tabular}{|c|c|c|c|}
\hline Characteristics & $\begin{array}{l}\text { Isolates } \\
(n=15)\end{array}$ & Characteristics & $\begin{array}{l}\text { Isolates } \\
(n=15)\end{array}$ \\
\hline Gram staining & - & Growth at $1 \% \mathrm{NaCl}$ & + \\
\hline Motility & + & Growth at $2 \% \mathrm{NaCl}$ & + \\
\hline Oxidase & + & Hemolysis & $\beta$ \\
\hline Catalase & + & Arginine dihydrolase & + \\
\hline $\mathrm{O} / \mathrm{F}$ & $\mathrm{F}$ & Ornithine decarboxylase & - \\
\hline $\mathrm{O} / 129(10-150 \mu \mathrm{g} / \mathrm{disc})$ & $-/-$ & Lysine decarboxylase & $\mathrm{V}$ \\
\hline Metil Red & + & \multicolumn{2}{|l|}{ Carbohydrate utilization } \\
\hline Voges Proskauer & - & Lactose & - \\
\hline Indole & + & Arabinose & + \\
\hline Citrate & - & Sucrose & + \\
\hline Nitrate & + & Mannitol & + \\
\hline Aesculine & + & Maltose & + \\
\hline Urease & - & Trehalose & + \\
\hline Growth on TCBS & yellow & Sorbitol & - \\
\hline Starch hydrolysis & + & Fructose & + \\
\hline Gelatin hydrolysis & + & Inositol & - \\
\hline Growth on MCA & + & Galactose & + \\
\hline Growth on BHIA & + & Xylose & - \\
\hline
\end{tabular}

+: positive reaction, -: negative reaction, V: variable, O/F: Oxidative/Fermentative MCA: MacConkey Agar

Table 2. Susceptibility of $A$. hydrophila isolates recovered from moribund guppy to 12 types of antibiotics

\begin{tabular}{|l|l|l|l|}
\hline Antibiotic $(\boldsymbol{\mu g} /$ disc $)$ & $\begin{array}{l}\text { Isolates } \\
(\mathbf{n}=\mathbf{1 5})\end{array}$ & Antibiotic $(\boldsymbol{\mu g} /$ disc $)$ & $\begin{array}{l}\text { Isolates } \\
(\mathbf{n}=15)\end{array}$ \\
\hline Flumequine $(30 \mu \mathrm{g})$ & $\mathrm{S}$ & $\begin{array}{l}\text { Sulphamethoxazole }(25 \\
\mu \mathrm{g})\end{array}$ & $\mathrm{S}$ \\
\hline Erythromycine $(15 \mu \mathrm{g})$ & $\mathrm{R}$ & Streptomycin $(10 \mu \mathrm{g})$ & $\mathrm{I}$ \\
\hline Kanamycin $(30 \mu \mathrm{g})$ & $\mathrm{I}$ & Chloromphenicol $(30 \mu \mathrm{g})$ & $\mathrm{S}$ \\
\hline Oxytetracycline $(30 \mu \mathrm{g})$ & $\mathrm{R}$ & Furazolidon $(50 \mu \mathrm{g})$ & $\mathrm{R}$ \\
\hline Ciproflaxacin $(1 \mu \mathrm{g})$ & $\mathrm{S}$ & Enrofloxacin $(5 \mu \mathrm{g})$ & $\mathrm{S}$ \\
\hline Ampicillin $(10 \mu \mathrm{g})$ & $\mathrm{R}$ & Florfenicol $(30 \mu \mathrm{g})$ & $\mathrm{S}$ \\
\hline
\end{tabular}

R: Resistant, I: İntermediate sentivite, S: Sensitive

\section{Discussion}

The bacterial diseases are the most important diseases in ornamental fishes and a significant cause of high mortality rates (Wildgoose,
2001). MAS is the most common bacterial disease of freshwater fish species. $A$. hydrophila, the agent of MAS, is a zoonotic 
pathogen (Li and Saghaian, 2011) and in human septic arthritis, diarrhea, corneal ulcers, skin and wound infections, meningitis and fulminating septicemia may be caused (Von Mensch, 1968).

In the present study, according to Gram staining, presence of cytochrome oxidase and catalase enzyme, fermentation, O/129 resistivity isolated bacteria were identified as Aeromonas sp. According to the other morphological and biochemical test result and API profile of our isolates, in present study isolated bacteria were identified as $A$. hydrophila and comparable to that recorded by Buller (2004), Austin and Austin (2016).

The gross pathology observed in our findings bear similarities to MAS in the other ornamental fish species (Hettiarachchi and Cheong, 1994) such as loss of the scales, hemorrhagic ulcerative skin lesions, and abdominal distension with an accumulation of liquid in the abdominal cavity. We think that ulcerative skin lesions observed moribund guppy may be on account of the chronic motile areomonas infection described by Huizinga et al (1979). Afifi et al. (2000) reported exophthalmia in the eyes of moribund Nile tilapia infected with $A$. hydrophila however; this clinical finding was not observed in the diseased guppy. Internally infected guppy exhibited pale liver because of bacterial toxins liver may become pale color as described by other researchers (Ventura and Grizzle, 1988; Afifi et al., 2000; Hamid et al., 2017).

Vacuolation and necrosis in the liver has been reported in different fish species such as $C$. punctatus, Oreochromis niloticus, Oreochromis aureus on account of toxins and extracellular products produced by $A$. hydrophila (Afifi et al., 2000; Laith and
Najiah, 2013; Al-Yahya et al., 2015). In this study, degeneration and necrosis were detected in the visceral organs such as liver, kidney and spleen, however hemorrhage and hyperemia reported by other researchers (Pal et al., 2015; Abdelhamed et al., 2017; Hamid et al., 2018) was not detected in the diseased guppy.

The resistance of $A$. hydrophila to commonly used antibiotics is an emerging problem in the ornamental fish. It has been reported that there is a resistance in A. hydrophila against a wide range of antibiotic compound such as chloramphenicol, erythromycin, streptomycin, ampicillin, novobiocin, streptomycin (Aoki, 1988). Tetracycline and oxytetracycline are commonly applied for the treatment of MAS (Laith and Najiah, 2013). However, in this study our isolates are resistant to oxytetracycline. This result shows that the use of uncontrolled antibiotics in fish production causes resistance of pathogenic bacteria. In addition, previous studies describe that Aeromonas strains are resistant to ampicillin (Radu et al., 2003; Dias et al., 2012). Similarly, in this study our isolates are resistant to ampicillin.

A. hydrophila causes serious health problems both fish in the aquarium and aquarist contact with infected fish. For this reason, it is important to determine the cause of the disease and to apply the appropriate treatment method for zoonotic agents like A. hydrophila. In this study, A. hydrophila were recovered from moribund guppy as primer disease. Uncontrolled treatment may cause resistance of pathogen bacteria; for this reason, especially treatment of zoonotic agents is important both aquarists through contact with infected fish and fish health. 


\section{References}

Abdelhamed, H., Ibrahim, I., Baumgartner, W., Lawrence, M. L., Karsi, A. 2017. "Characterization of histopathological and ultrastructural changes in channel catfish experimentally infected with virulent $A$. hydrophila". Frontiers in Microbiology, 8, 15-19.

Afifi, S. H., Al-Thobiati, S., Hazaa, M. S. 2000. "Bacteriological and histopathological studies on Aeromonas hydrophila infection of Nile tilapia (Oreochromis niloticus) from fish farms in Saudi Arabia", Assiut Veterinary Medical Journal, 84, 195-205.

AlYahya, S. A., Ameen, F., Al-Niaeem, K. S., Al-Sa'adi, B. A., Hadi, S., Mostafa, A. A. 2018. "Histopathological studies of experimental Aeromonas hydrophila infection in blue tilapia, Oreochromis aureus", Saudi Journal of Biological Sciences, 25(1), 182185.

Aoki, T. 1988. "Drug-resistant plasmids from fish pathogens", Microbiological Sciences, 5(7), 219-223.

Austin, B., Austin, D. A. 2016. "Bacterial fish pathogens, diseases of farmed and wild fish $6^{\text {th }}$ edition”, Springer, Dordrecht, 119-131.

Barry, A. L., Thornsberry, C. 1985. "Susceptibility tests: diffusion test procedures", Manual of Clinical Microbiology, 4 th edition, Washington, American Society of Microbiology, 978-987.

Buller, N.B. 2004. "Bacteria from fish and other aquatic animals: A practical identification manual", Wallingford, UK, CABI Publishing.

Bullock AM, 1978. "Laboratory methods in fish pathology", Bailliere Tindall, London, 235- 267.

Clinical and Laboratory Standards Institute (CLSI). 2008. Performance standards for antimicrobial disk and dilution susceptibility tests for bacteria isolated from animals: approved Standard-Third edition M31-A3. CLSI, Waune, PA, USA.
Dias, C., Mota, V., Martinez-Murcia, A., Saavedra, M. J. 2012. "Antimicrobial resistance patterns of Aeromonas spp. isolated from ornamental fish", Journal of Aquaculture Research and Development, 3(3), 131-136.

El-Barbary, M. I. 2010. "Some clinical, microbiological and molecular characteristics of Aeromonas hydrophila isolated from various naturally infected fishes", Aquaculture International, 18(5), 943-954.

Hamid, N.H., Hassan, M.D., Sabri, M.Y.M., Hasliza, A. H., Hamdan, R. H., Afifah, M. N. F., Raina, M. S., Nadia, A. B. S., Fuad, M. M. 2017. "Studies on pathogenicity effect of Aeromonas hydrophila infection in juvenile red hybrid tilapia Oreochromis sp., Proceedings of International Seminar on Livestock Production and Veterinary Technology, 532-539.

Hettiarachchi, D. C., Cheong, C. H. 1994. "Some characteristics of Aeromonas hydrophila and Vibrio species isolated from bacterial disease out-breaks in ornamental fish culture in Sri Lanka", Journal of the National Science Foundation of Sri Lanka, 22(3), 261269.

Huizinga, H.W., Esch, G.W., Hazen, T.C. 1979. "Histopathology of red-sore disease (Aeromonas hydrophila) in naturally and experimentally infected largemouth bass Micropterus salmoides (Lacépéde)", Journal of Fish Diseases, 2, 263-277.

Jagoda, S. D. S., Wijewardana, T. G., Arulkanthan, A., Igarashi, Y., Tan, E., Kinoshita, S., Asakawa, S. 2014. "Characterization and antimicrobial susceptibility of motile aeromonads isolated from freshwater ornamental fish showing signs of septicaemia" Diseases of Aquatic Organisms, 109(2), 127-137.

Janda, J. M., Abbott, S. L. 2010. "The Genus aeromonas: Taxonomy, pathogenicity, and infection", Clinical Microbiology Review, 23, 35-73. 
Laith, A. R., Najiah, M. 2013. “Aeromonas hydrophila: antimicrobial susceptibility and histopathology of isolates from diseased catfish, Clarias gariepinus (Burchell)", Journal of Aquaculture Research and Development, 5(2), 1-7.

Lewbart, G. A. 2001. "Bacteria and ornamental fish. In Seminars in avian and exotic pet medicine", Elsevier, 10 (1), 48-56.

Li, X., Saghaian, S. H. 2011. Impact of HACCP on US Seafood Exports. Paper presented at IFAMA meeting, Frankfurt, Germany, June 20-23.

Musa, N., Wei, L. S., Shaharom, F., Wee, W. 2008. "Surveillance of bacteria species in diseased freshwater ornamental fish from aquarium shop", World Applied Sciences Journal, 3, 903-905.

Pal, S., Ray, S. D., Homechaudhuri, S. 2015. "Evaluation of in vivo non-specific immunity and oxidative stress in Labeo rohita (Hamilton, 1822) infected with Aeromonas hydrophila as biomarker for early diagnosis", Int J Fish Aquat Stud, 3(1), 116124.

Pathiratne, A., Widanapathirana, G. S., Chandrakanthi, W. H. S. 1994. "Association of Aeromonas hydrophila with epizootic ulcerative syndrome (EUS) of freshwater fish in Sri Lanka", Journal of Applied Ichthyology, 10, (2), 204-208.

Radu, S., Ahmad, N., Ling, F. H., Reezal, A. 2003. "Prevalence and resistance to antibiotics for Aeromonas species from retail fish in Malaysia", International Journal of Food Microbiology, 81(3), 261-266.

Savaş, E. 1996. Marmara bölgesindeki akvaryum balığı işletmelerinin ekonomik analizi. Istanbul Üniversitesi, Fen Bilimleri Enstitüsü, Yetiştiricilik Anabilim Dalı, Yetiştiricilik Programı, Yüksek Lisans Tezi, İstanbul.

Türkmen, G., Alpbaz, A.G. 1999. "Türkiye' de akvaryum balıkçılığı”, İstanbul Üniversitesi Su Ürünleri Dergisi Özel Sayı, 469-474.
Ventura, M. T., Grizzle, J. M. 1988. "Lesions associated with natural and experimental infections of Aeromonas hydrophila in channel catfish Ictalurus punctatus (Rafinesque)". Journal of Fish Diseases, 11, 397-407.

Von Gravenitz, A., Mensch, A. H. 1968. The genus Aeromonas in human bacteriology", New England Journal of Medicine, 278, 245 249.

Wildgoose, W. 2001. "BSAVA Manual of ornamental fish, 2nd ed", British Small Animal Veterinary Association, Quedgeley, Gloucester, UK, 312. 